\title{
A Comparison of the Effects of 1929 Great Depression With the Effects of 2008 Global Financial Crisis: Policies Pursued in the Developed, Less Developed and Newly Industrializing Countries
}

\author{
Özlen Hiç-BİROL \\ İstanbul University, İstanbul, Turkey
}

\begin{abstract}
A comparison of the Great Depression of 1929-1939 with the present global financial crisis and global recession that broke out in the last quarter of 2008 will provide useful insights about economic developments in the world and changes and progress in the understanding of economics and implementation of economic policies. There is no doubt that the Great Depression was the deepest depression compared with the previous business cycles and depressions and, thankfully it was never paralleled. The 2008 economic crisis, on the other hand, was the worst encountered excepting the former mentioned. At the time of the 1929 Great Depression, however, economic theory, hence economic policy implementation was not too advanced to draw out effective anti-depression policies. In fact, most policies implemented by the USA and European countries actually deepened and lengthened the depression. In contrast, the 2008 economic crisis took place in a highly globalized world and when countries were at a much higher economic and technological level compared with 1929 Great Depression. Economic theory had also progressed sufficiently to guide countries to implement policies that prevent the recession and at least that prevent it to grow further into a deep depression. Within a highly globalized world economy, the financial crisis and recession fast spread throughout the world, the developed, the less developed, and newly industrializing countries as well as the emerging markets. But all countries were quick to implement effective measures against it in a milieu of cooperation. Thus, as the crisis was globalized, the response to the crisis was also globalized. A short review of the Great Depression followed again by a short account of the present economic crisis will bring to light the above points more clearly. The first part of the article will cover a review of the 1929-1939 Great Depression and the developments since the Great Depression up till the present times. The second part will cover the 2008 Financial Crisis and its effects on the developed countries (DCs), namely, USA, Europe, and Japan, the effects on the less developed countries (LDCs), newly industrializing countries (NICs) and Balkan, Russia, India and China (BRICs) will be followed before dealing with the after-effects of the crisis and reaching the conclusions.
\end{abstract}

Keywords: Great Depression, global financial crisis, economic policies, policy measures during crisis

\section{Understanding the Great Depression 1929-1939}

The 1929 Great Depression had started in the banking sector of the USA, following the 1914-1918 World War I and a short-lived economic revival in the 1920s. Herbert Hoover of Republican Party, the US president at

Özlen Hiç-BİROL, Assistant Professor, Economics in English Department, İstanbul University.

Correspondence concerning this article should be addressed to Özlen Hiç-BİROL, İstanbul University, Economics Faculty, Economics in English Department, Beyazıd, İstanbul-Turkey. E-mail: ozlen.h.birol@gmail.com. 
the time responded by wrong economic measures. Firstly, he restricted imports in order to achieve foreign trade balance and thus prevent the flight of gold. This was, in fact, a beggar-thy-neighbor policy hurting all the countries, including the USA. Secondly, he abstained from intervening the economy. He did not expand government expenditures to fight the depression. Neither did he take effective measures to solve the banking crisis nor to ameliorate the plight of workers and farmers. The current economic theory and macro system at the time was that of the Classical school and Classical economists believed that full employment would be achieved automatically in the competitive markets; hence, no government intervention to the economy was required. But the Classical macro system was unable to explain convincingly the business cycles and the depression met throughout since the industrial revolution. As a result of this hands-off policy, hundreds of banks in the USA went bankrupt; unemployment reached very high levels, one fourth of farmers lost their lands.

Thus in the 1932 elections, Franklin D. Roosevelt of Democrat Party won the presidency and he immediately implemented a program called the "New Deal". The major aim of this program was to ameliorate the plight of the farmers and the workers. By 1935 Roosevelt reformed the social security system of the workers and introduced unemployment insurance. Otherwise, however, he kept the level of government expenditures restricted. Though he was three times elected as president, consecutively because of the social measures he tried to implement the depression in the USA lingered for quite some time till the World War II because of the lack of aggregate demand and because the government expenditures were not raised out of fear of budget deficits and inflation. Thus, low private consumption and investment expenditures were not compensated by higher public expenditures.

The world was implementing the gold monetary system at the time of the depression. During World War I the gold system had to be abandoned because of difficulties of meeting international debt payments in gold. But because of budget deficits, the paper money regime that had to be implemented during the war years went hand in hand with inflation. Therefore, after World War I all countries had returned to the gold monetary system.

European countries too fell victim to the Great Depression simultaneously with the USA, the problems again starting with payment difficulties of the financial sector. Similar to the USA, European governments also made the same two policy mistakes. Firstly, they restricted imports, trying to attain foreign trade balance. But, when a country restricts its imports, it means exports of all other countries are decreased, hence the growth rate falls, leading to less demand for exports from other countries, that is, countries that restrict their imports. Therefore, it is, in fact, a beggar-they-neighbor policy as mentioned above, depressing the growth and income of all countries, hence deepening the depression. The effects of import restrictions were such that by 1932 the total volume of world trade had fallen down to only half of its 1928 level. Secondly, again similar to the USA, the European governments also refrained from expanding government expenditures to fight the fall in income levels. This further deepened the depression and increased unemployment levels.

In 1936, observing that the classical economic system did not hold and could not solve the problem of recessions and depressions, Keynes published his famous path breaking book (The General Theory of Employment, Interest and Money). Keynesian macroeconomic system emphasized that, contrary to the Classical system, full employment is not achieved automatically; hence government intervention at the macro level is required to bring about full employment. During the times of depression, according to the Keynesian system, fiscal policy (of increasing government expenditures or lowering taxes) is much more effective than monetary policy (of expanding money supply and lowering the interest rates). During and after the World War II 
most countries chose not to return to the gold system, but remained with the paper money regime because it was a more convenient monetary system to implement monetary policy. The USA, in contrast, having a relatively large volume of gold, remained at the gold system for a longer time, but eventually abandoned it in the early 1970s. The US dollar, however, remained as the world's most widely used reserve currency.

The Great Depression had also triggered serious political upheavals. In Germany, the economic and political turmoil of the depression plus heavy World War I indemnity payments demanded from Germany finally brought Adolf Hitler and National Socialists to power in 1933, leading to World War II 1939-1945. In Italy, Fascist Benito Mussolini had already come to power in 1922; he sided with Germany and Hitler in World War II.

All developed countries (DCs) implemented Keynesian macroeconomic policies since World War II and prospered steadily, with business cycles depression and inflations averted, up until the oil price rises by OPEC in early 1970s which gave rise to stagnation and inflation (stagflation).

\section{Developments Since the Great Depression Up Till Present}

Following World War II (1939-1945) immediate steps had been taken not to fall back to international trade restrictions that had been implemented after the World War I and during the Great Depression. Accordingly, with the 1944 Bretton Woods agreement IBRD (WB) and IMF were established and GATT (General Agreement on Tariffs and Trade) was reached in 1947. They aimed to secure and maintain liberalized international trade, to lend short term credit to countries facing trade deficits and to lend long term investment credit first to Europe for re-construction, and then to the developing countries to aid their development. By 1970s most of all the less developed countries (LDCs) and newly industrializing countries (NICs) facing recurring foreign trade crises, hence lowering of growth rates accompanied by high inflation reverted from closed economy, import-substitute industrialization model and fixed foreign exchange regime to open economy model and market economy with flexible exchange rate regime, aided in this direction by the advices of IMF and WB as well as their free and deliberate choice. Both international trade (exports and imports) as well as Direct Private Investments (DPIs) increased steadily all throughout, including not only between the developed countries but also from the DCs to the LDCs and to some extent also between the LDCs. International migration (both legal and illegal), remittances of international migrants to home country as well as tourism also increased steadily. After USSR was dismantled most of the Eastern European and Balkan countries that gained full independence also opted for the market economy and relations with the West, including membership to NATO as well as to the EU. At the same time, since the 1990s particularly short term financial flows (lending credit, buying government or private bond or shares) from the DCs to the LDCs and NICs also increased substantially, thus leading to a globalized world. Globalization raised the growth levels of all countries, up until 2007. The growth rates of LDCs and NICs rose even faster than those of DCs. In particular, Brazil, Russia, India, and China (BRIC) registered remarkably high growth rates and economic transformation and these countries began to be called "emerging markets". China, who is interesting to underline, had abandoned production by state enterprises, had entered World Trade Organization (WTO), and had become a major recipient of DPIs coming mostly from the USA, Europe, and Japan. Thus, the global financial crisis and global recession (in short, global economic crisis) hit the world in September 2008 when the world had become highly globalized and incomes had risen to high levels, accompanied by decreased numbers of people below the poverty line for the world in general. 


\section{The 2008 Financial Crisis and Its Effects on the Developed Countries}

\section{Recession in the USA}

The 2008 financial crisis again first broke out in the USA, as had been the case for the Great Depression. There were several factors why the financial crisis broke out. Firstly, the financial sector had been largely deregulated since the Reagan era in the USA, similarly with UK since the Thatcher era. Secondly, consumers incessantly demanded higher level mortgage credits from banks and mortgage institutions, based on the assumption that house prices would continue to rise in future as had been the case in the past years. Thirdly, banks were too eager to grant such mortgage credits in order to increase their profits (not writing them off as bad or even risky "debts", i.e., "credits" from the point of view of banks. Thus, salaries and premiums of CEOs of banks and financial institutions concerned were raised along with reported increases in profits, so did the value of shares of the shareholders and dividends they received. But with the slowing down and then falling house prices, both the debtors to the bank who had received mortgage credits as well as the banks suffered. Fourthly, financial sector is a particular sector which requires an optimum dose of regulation and control and should not be deregulated. But both the government (the Secretary of the Treasury) and also the chairman of the FED at the time (Alan Greenspan) failed to see the future risks involved, hence the financial sector was kept largely deregulated during the George Bush era until the crisis broke out.

First it was supposed that banks suffered an "illiquidity" problem, but it was soon realized that it was a much deeper and wider "insolvency" problem when many large banks and institutions dealing with mortgage credits faced bankruptcy and had to apply for government help. Mortgage institutions, banks as well as "hedge funds" (institutions investing the money of savers to profitable valuable papers) which held valuable papers tied to mortgage debts all had suffered.

This time, however, unlike the experience of the Great Depression, the government (the Treasury) immediately acted to rescue the insolvent banks and institutions. In some emergency cases, the Treasury put in money to partly nationalize the ailing institutions. For other cases the Treasury established a special fund to buy off these mortgage "debts" (i.e., credits of the banks) whose value had become worthless. The fund was called Troubled Assets Relief Program (TARP). These "assets" were called "toxic assets" because their presence affected the overall liquidity and solvency of the bank in question. The bank was then allowed either to go on independently or else was encouraged to be sold to another but healthy bank. At the same time, the FED (Ben Bernanke as chairman) decreased the interest rate (as far as down to $0.5 \%$, i.e., to about zero) while it increased its facilities for encouraging interbank credits. The funds appropriated by the FED far exceeded $\$ 1$ trillion. These measures by the FED were aimed to encourage private investments as well as private consumption at low interest rates, and also to expand the credit availability of banks. Measures to save the financial sector were effective in the sense that it prevented a total collapse of the financial sector; insolvencies and bankruptcies were largely prevented. But these monetary measures were not enough to stimulate the economy and take it out of recession. To fight the recession, the fall in the level of private investments and consumption, therefore, the US government put into effect a special program of increased public investments (in infra-structure, clean energy, etc. for the case of USA). After Obama became president, he disallowed bank nationalizations, but preferred to lend credits to banks in trouble within a newly set-up and enlarged fund. But he also forced them to undergo special tests (called stress tests) for their financial strength to withstand certain assumed negative developments in the economy. Of the $\$ 700 \mathrm{bn}$. TARP, the previous fund, the remaining $\$ 350 \mathrm{bn}$. was 
transferred to the new fund of $\$ 1$ trillion, which was later raised to $\$ 2$ trillion, and participation of private firms specialized in purchases of bad assets was secured. Obama continued, however, with the public investment program, adding to its health care improvements. In fact, long ago, in 1936 Keynes had warned that to prevent recessions and depressions, effectiveness of monetary policy would be limited while fiscal measures (raising government expenditures) would definitely bear out results. Thus, the economy could not be turned around immediately to move up, but at least a serious depression was averted, the financial crisis and the recession were, in fact, ameliorated. By late 2009 real estate prices finally stopped falling down, bank insolvencies and illiquidity problems were largely subsided. Hence problems started to soften by 2010 but full recovery was not attained up till present. It is true that the programs designed to help the ailing financial sector and to increase public investments raised the level of government debt and budget deficits to record levels, all to be paid in future. But had the programs not been put into effect, the cost to the economy both for the present and for the future would have been much higher in terms of growth, income, and tax revenue levels while we would also be faced with a very large increase in unemployment.

Next to the financial sector and the house construction sector, all sectors were negatively affected, but the automotive sector suffered most from the recession and hence was a special sector for government aid in the USA, as well as in all other countries. In the USA, GM, and Chrysler, in particular, suffered most. Therefore, the government lent them credit in a limited way, but since both had also faced structural problems, the government asked GM to prepare a program of reform, including lowering of personnel salaries and workers' wages. For Chrysler, the government urged similar restructuring and sale of a substantial part of its shares to Italian Fiat. GM, faced with $\$ 173$ bn. debt finally had to apply to the Treasury for bankruptcy protection and had to be $60 \%$ nationalized as the first step. Opel, a GM subsidiary in Germany was sold to Magna, a large Canadian auto parts firm at the head of a consortium. It was finally decided, on the other hand, to sell $20 \%$ of the shares of Chrysler to Fiat.

In sum, however, although a serious depression was averted the measures taken led to large budget deficits as well as large balance of payments deficits and very high volumes of external debt for the case of USA. These developments continue to create economic problems presently.

\section{Recession in Europe and Japan}

Both the financial crisis and the recession soon spread to the developed European countries and Japan. Firstly, European and Japanese banks held assets of US banks and financial institutions which had become worthless, hence suffered illiquidity and insolvency, leading to a financial crisis in these countries. The European governments also intervened immediately, some banks were partly nationalized in some countries, some were sold to other banks, and some received government credit to bail them out. Secondly, exports of these countries to the USA decreased, thus further triggering the recession. Financial difficulties of exporting firms, in turn, squeezed the banks even further. With falling and negative growth rates, similar to the USA, private investments and private consumption also decreased. The European and Japanese governments, likewise, again immediately intervened and put in force special government expenditure program to ameliorate the recession. Again the Central Banks of European countries and Japan as well as the European Investment Bank (EIB) lowered interest rates to encourage private investments and private consumption as well as to strengthen the banks and aid them to continue giving out credits. The automotive sector in the developed countries also suffered most from the recession and had to be aided by the governments. Generally, these 
governments chose to aid their automotive sectors by offering to pay a certain sum to the scrapped old vehicles to the buyers of new cars with up-to-date emission standards. In the case of France, the French government further lent credit to French automakers while Sarkozy prevented any sales of companies to be taken over by non-French firms, even by firms from the EU countries.

Generally, European countries implement deeper welfare measures, including social security system, health care, unemployment insurance etc.. These measures taken as a whole tended to depress the growth rates of European countries compared with the USA and UK, during the recession this time they helped by preventing incomes and hence private consumption from falling more precipitously. Only the French government implemented relatively intensive interventions and controls during the crisis, but it was temporary though in general the French economic regime is more interventionist compared with, say Germany, and naturally the USA and Japan. One thing, however, became certain, financial sectors were kept regulated with care taken not to fall into over-regulation. The government sector was also somewhat enlarged because some of the measures such as improvements in health care, etc. remained permanently. It would take time to denationalize the banks that had to be speedily nationalized partly when the financial crisis broke out.

\section{The 2008 Financial Crisis and Its Effects on the LDCs, NICs, and BRICs}

The global recession of 2008 also spread to the LDCs and NICs as well as the emerging markets. Firstly, most of these countries were exporting to the USA and Europe and along with the recession in the latter countries, their exports declined considerably. Secondly, they relied on DPIs and financial flows coming from the developed countries for stimulating faster growth. But due to the financial crisis and recession in the developed countries these flows also declined, similarly even remittances of workers. China could implement an anti-recessionary public investment program financed by the foreign exchange reserves that she had accumulated. Brazil also suffered the least because of wise and pragmatic economic policies she had pursued since Lula de Sylva came to power. India was also the least affected. But countries like Russia and Turkey which had depended on ever increasing external borrowing to finance a faster growth rate, suffered more because of the shrinking foreign exchange inflow, including not only exports but also short-term credits as well as DPIs. Ukraine was also another country seriously affected by the present economic crisis. Thus, in future, countries like China, Japan, and Germany have to rely less on an export-oriented growth strategy but also encourage domestic private consumption, while Russia will have to rely less on external debt financing of growth and development but keep relying on DPI flows. Countries like USA, UK, on the other hand, will have to increase their savings in order to keep their private consumptions as well as imports not to rise above sustainable levels. China, in addition, should raise the value of the yuan and refrain from artificial export promotion and over-accumulation of foreign exchange reserves.

\section{A Short Overview of the After-Effects of the 2008 Economic Crisis}

For the case of the USA, the more serious problems arising out of economic measures to avoid the 2008 economic crisis were increased external debt, increased trade and current account deficit as well as increased budget deficit. The Senate and the House of Representatives had to raise the level of external debt legally allowed in order to avoid a catastrophe. Otherwise, the US economy continues to register some growth.

On the other hand many European countries, in particular, those in the Euro zone have, at present, that is, by 2011 and 2012 displayed serious economic difficulties, such as high external debt, inability to pay this debt 
as well as some weak points or banks in their financial sector. These countries included Greece, Ireland, Spain, Portugal, and Italy, these problems also even in France. Despite help from the European Union, European Central Bank and IMF, these problems continue to threaten the stability of the Euro zone. But these present economic problems are only loosely related to the after-effects of the economic measures implemented during 2008 economic crisis.

At this point, we should have to mention Turkey as a special case. Although Turkey was one of the countries worst hit by the 2008 global economic crisis, she made a very swift recovery. Hence she enjoys a very high growth rate and continued flow of DPIs. On account of economic problems faced in Europe, the Turkish government deliberately sought to increase exports to other countries, which it did successfully. But increased trade and current account deficit and increased external debt remain a potential future threat. If the Euro zone and EU countries go into a continued recession, Turkish economy would definitely be negatively affected.

\section{Conclusions}

As the above explanations reveal, the magnitude of the 2008 global economic crisis was very high and due to globalization the crisis had immediately spread throughout the whole world. But, in contrast to the wrong policy implementations during the Great Depression, this time the right economic policies, on the whole, were implemented by nearly all countries. Hence the response to the crisis by the governments and the Central Banks were also global, that is, in harmony and in cooperation, broadly speaking. Therefore, though the crisis was the worst experienced since the Great Depression, the recession was not allowed to develop into a depression. Measures taken to prevent the 2008 crisis, however, gave rise to problems of external debt, budget deficits as well as trade deficits presently, that is, by 2011 and 2012. This is certainly the case with the USA, while many countries in the Euro zone and China as well as Turkey, on the other hand, are in a much better position compared with other countries.

\section{References}

Balassa, B. (1971). Trade policies in developing countries. American Economic Review, 61, 178-187.

Balassa, B., \& ASSOCIATES. (1982). Development strategies in semi-industrial countries. Baltimore: Johns Hopkings University Press.

Bauer, P. T. (1972). Dissent on development. London: Wiedenfeld and Nicholson.

Bhagwati, J. N. (2004). In defense of globalization. New York: Oxford University Press.

Bhagwati, J., \& Srinivasan, T. N. (1975). Foreign trade regimes and economic development: India. New York and London: Columbia University Press.

Cardoso, F. H., \& Faletto, E. (1979). Dependency and development in Latin America. Los Angeles: University of California.

Coale, A. J., \& Hoover, E. M. (1958). Population growth and economic development in low-income countries: A case study of India's prospects. Princeton, N.J.: Princeton University Press.

Hiç, M. (2001). Ellili Yıllardan Günümüze Kalkınma Ekonomisi (Development economics since the years fifties till present). İstanbul: İstanbul University.

Hiç, M. (2008). A survey of Turkey's economy and politics. Create-Space, Amazon Co..

Hiç, M. (2010). Major current economic and political problems facing Eurasian countries. Proceedings from the International Conference on Eurasian Economics 2010. Istanbul: Beykent University.

Kennedy, P. (1993). Preparing for the twenty first century. Toronto: Amazon Co..

Kindleberger, C. P. (1958). Economic development. New York: McGraw-Hill.

Krueger, A. O. (1974). Political economy of a rent-seeking society. American Economic Review, 64, 291-303.

Krueger, A. O. (1983). Trade and in developing countries. Chicago: University of Chicago Press. 
Lal, D. (1983). The poverty of development economics. London: Institute of Economic Affairs Hobart 16.

Lall, S. (1981). Developing countries and international economy. Basingstoke: Macmillan.

Lewis, W. A. (1954). Economic development with unlimited supplies of labour. Manchester School of Economic and Social Studies, 22, 139-191.

Little, I. M. D., \& Mirrless, J. A. (1974). Project appraisal and planning for developing countries. London: Heineman Educational.

Little, I. M. D., Scitovsky, T., \& Scott, M. F. G. (1970). Industry and trade in some developing countries. London: Oxford University Press.

Myrdal, G. (1959). Economic theory of underdeveloped regions. London: Duckworth.

Nurkse, R. (1952). Some international aspects of the problem of economic development. American Economic Review, 42, 571-583.

Prebisch, R. (1988). Dependence, development and interdependence. In G. Ranis, \& T. P. Schultz (Eds.), The state of development economics. Oxford, United Kingdom: Basil Blackwell.

Ranis, G., \& Fei, C. H. (1961). A theory of development. American Economic Review, 51(4), 566-593.

Rodrik, D. (1999). The new global economy and developing countries: Making openness work. Washington, D.C.: Johns Hopkins University Press.

Toye, J. (1993). Dilemmas of development (2nd ed). Oxford: Blackwell. 